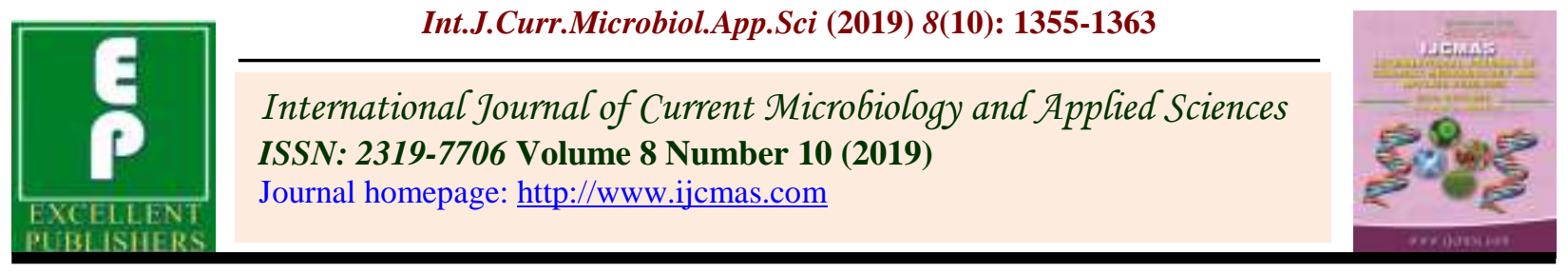

Original Research Article

https://doi.org/10.20546/ijcmas.2019.810.158

\title{
Productivity and Economics under Varying Sowing Time of Mustard (Brassica juncea L.) Varieties in Central Uttar Pradesh
}

\author{
Naresh Chand ${ }^{1}$, A. P. Dubey ${ }^{1}$, Thaneshwar ${ }^{2}$, Jai Prakash ${ }^{2}$ and Vipin Kumar Sagar ${ }^{2 *}$ \\ ${ }^{1}$ Department of Agronomy, C.S.A.U.A.\&T. Kanpur (Uttar Pradesh)-208002, India \\ ${ }^{2}$ Department of Agronomy, S.V.P.U.A.\&T. Meerut (Uttar Pradesh)-250110, India \\ *Corresponding author
}

\section{A B S T R A C T}

\section{Keywords}

Mustard, Sowing time, Crop growth, Seed yield

\section{Article Info}

Accepted:

12 September 2019

Available Online:

10 October 2019
A field experiment was conducted at Student Instructional Farm, C.S. Azad University of Agriculture and Technology, Kanpur with three dates of sowing viz. November, 03, 10 and November, 17, 2011 and used three varieties of mustard viz. Vaibhav, Vardan and Varuna with four replication under Split Plot Design. Plant height, number of branches, number of siliquae, number of seed/siliquae, dry matter, seeds weight and yield were recorded at different growth stages. All the biometric parameters decreased with delay in sowing. Among the different varieties of mustard, Varuna showed higher plant height, more primary, secondary and tertiary branches, more dry weight and yield as compared to Vardan and Vaibhav. Higher seed yield (21.05 q/ha) was recorded under November, 03 date of sowing, when maximum and minimum temperature was 32.8 and $13.0^{\circ} \mathrm{C}$ respectively as compare to November, 17 (Maximum $30.2^{\circ} \mathrm{C}$ and Minimum $13.4^{\circ} \mathrm{C}$ ) sown crop. Subsequently, sowing there was 12 and $22 \%$ increases in seed yield at November, 03 sowing over one and two week delayed sown crop. Among the varieties mean yield of Varuna yielded $20.06 \mathrm{q} /$ ha and performed 8.3 and $12.3 \%$ higher yield than Vardan and Vaibhav, respectively. Net profit was calculated maximum (Rs 66265/ha) under $3^{\text {rd }}$ Nov. of sowing $\left(D_{1}\right)$ over to $10^{\text {th }} \operatorname{Nov} .\left(D_{2}\right)$ and $17^{\text {th }}$ Nov. $\left(D_{3}\right)$ as well as the net profit was received among the varieties Varuna was produces maximum (Rs.61621/ha) over to Vardan (Rs 54266.00/ha) and Vaibhav (Rs 50596/ha).

\section{Introduction}

Rapeseed mustard (Brassica Spp.) group of crops is the second most important oil seed crop of the country after groundnut contributing nearly $25-28 \%$ of total oil seeds production. Oil and fats are essential ingredients of balanced food and constituent of human body. These have medicinal and therapeutic value (Krishna Murthy and Bhatnagar, 1998). The oil seed scenario in the country has undergone a sea of change in the last fifteen years. India was importing edible oil and fats till mid 1980's; started exporting during the early 1990's and thereafter status importing more than $40 \%$ of annual edible oil needs (Hundal et al., 2004). Oilseed crop held a sizeable share of the country's gross cropped 
area $(14 \%)$ and contributed around $1.4 \%$ of the value of all agricultural commodities. Presently, India is playing a vital role in global demand spectrum of oilseed through accounting for about 12-13 per cent of world oilseed area, 6-7 per cent of world oilseed output, 6-7 per cent of world oil meal production, 5-6 per cent of world oil meal export, 6-7 per cent of world vegetable oil production, 15-17 per cent of world vegetable oil import and 10 per cent of the world edible oil consumption.

In India, it is mainly cultivated in Rajasthan, Uttar Pradesh, Madhya Pradesh, Bihar, Assam, Gujarat, Maharashtra, Haryana and West Bengal in varied situation. In Uttar Pradesh rapeseed mustard is grown in an area of 6.2 lakh hectare with the production of 0.73 million tones and the productivity is 11.58 $\mathrm{q} / \mathrm{ha}$.. Rape seed mustard oil is used primarily for edible purpose and in the principal cooking oil in the mustard growing area of the country. Besides, seeds are used as condiments and in preparation of salad, juice curries and pickles.

The meal cake left after oil extraction form important cattle feed and may also be as organic manure.

In spite of fact that Indian mustard plays such a prominent role in agriculture economy. It has very low yield. There are several factors responsible for low yield. The important ones are delayed sowing, inadequate fertilizer application and various biotic and abiotic stresses. There situation are further aggravated by the fact that mustard is cultivated on marginal and sub marginal lands and also predominantly as mixed crop under rainfed condition. The limited improvement in this crop has been mainly due to narrow genetic base arbitrary choice of parents without understanding their genetic architecture and combing ability. During the past research efforts were made to evolve high yielding varieties to meet the growing demand of edible oil. Specially mustard oil which have been developed and oil seed production has also increased but due to growing demand of edible oil. There is a necessity the productivity of this crop at national level rapeseed and mustard covered 7.06 million hectare area and produced 4.7 million tonnes with productivity $1013 \mathrm{~kg}$ per hectare.

Agriculture production is most sensitive and vulnerable to climate change, as climate is the primary determinants of agriculture productivity is projected to decrease for the increase of local temperature $\left(1-2{ }^{\circ} \mathrm{C}\right)$ at lower latitudes, especially in seasonal dry and tropical/sub-tropical regions of the world (Anonymous,2007).

Mustard is considerably sensitive to weather as evidenced from the variable response to different dates of sowing (Kumar et al., 1998; Kar and Chakravarty 2000; Yadav et al., 2007), one month delay in sowing from mid of October resulted losses of $40.6 \%$ in seed yield (Lallu, et al., 2010). The temperature is major factor that directly affects insect development, reproduction and survival. Although the behavior of individual insect may vary to global climate change (rise in temperature) the impact of global warming on plant insect interaction has been predicted to increase the intensity of herbivore pressure on plants (Dhaliwal, 2002). Therefore, the present study was carried out to investigate Productivity and economics under varying sowing time of mustard (Brassica juncea L.) varieties in Central Uttar Pradesh

\section{Materials and Methods}

The field experiment was conducted during rabi seasons of 2011-12 at Student's Instructional Farm of C.S. Azad University of Agriculture and Technology, Kanpur (U.P.). Geographically, Kanpur is situated in 
subtropical region. It is situated at an elevation of 125.9 meter above mean sea level, $26^{0} 20^{\prime \prime}$ $35^{\prime \prime}$ North latitude and $80^{\circ} 188^{\prime} 35^{\prime \prime}$ East longitude. The mean annual rainfall is about $868 \mathrm{~mm}$ mainly through south-west monsoon rains confined within June to last week of September with occasional frost and shower in winter season from North-East monsoon during December and January. During the experiment, the mean minimum and maximum temperature varied in between 4.1 to 15.9 and 18.0 to $32.1^{\circ} \mathrm{C}$, respectively.. As far as total amount of rainfall is concerned, $67.6 \mathrm{~mm}$ rains were recorded during whole growth period. The sunshine hours ranged from 0 to 9.3 hours during experiment. The crop received cumulative sunshine hours of about 109.5 hours during the experiment. Soil samples from a depth of 0-15 $\mathrm{cm}$ were collected from each plot of the experiment with the help of soil auger prior to fertilizer application and composite sample was drawn for determining its physical and chemical properties. The soil of experimental site was sandy loam in texture (51.2 \% sand, $23.6 \%$ silt and $25.2 \%$ clay), low in organic carbon $(0.47 \%)$ and available nitrogen $(223 \mathrm{~kg} / \mathrm{ha})$, high in available phosphorus $(12.6 \mathrm{~kg} / \mathrm{ha})$ and medium in available potassium $(155 \mathrm{~kg} / \mathrm{ha})$ with near to neutral $(7.70 \mathrm{pH})$ in reaction. The experiment was conducted in split plot design (SPD). Nine treatments combination comprised of three sowing date/sowing temperature viz. crop sown on November 03 at sowing mean temperature $22.9{ }^{0} \mathrm{C} \quad\left(\mathrm{D}_{1}\right)$. Crop sown on November 10 at sowing mean temperature $21.8^{\circ} \mathrm{C}\left(\mathrm{D}_{2}\right)$ and crop sown on November 17 at sowing temperature $21.8^{\circ} \mathrm{C}\left(\mathrm{D}_{3}\right)$ along with three varieties i.e. Vaibhav, Vardan, and Varuna were used under investigation, keeping dates of sowing in main plots and variety of mustard in sub plots with 3 replications. The preparation of field by ploughing once with tractor drawn mould board plough, twice by cultivator which followed by planking. Each operation was followed by planking to have smooth clod free seed bed. After land preparation the layout of all the experiment was marked and sub-plots were demarcated within each main plot. Fertilizers were applied during last operation of field. The experimental crop was fertilized @ $120 \mathrm{~kg} \mathrm{~N} / \mathrm{ha}, 60 \mathrm{~kg} \mathrm{P}_{2} \mathrm{O}_{5} / \mathrm{ha}, 60 \mathrm{~kg} \mathrm{~K}_{2} \mathrm{O}$ and $25 \mathrm{~kg} \mathrm{~S} / \mathrm{ha}$ only half of the nitrogen was applied at the time of sowing while rest half amount of nitrogen was applied in two equal splits, each at optimum soil moisture after first irrigation and 60 days after sowing through urea and phosphorus and potash full doses were applied in deep furrows at the time of sowing. On next day after sowing, lay out was prepared with help of hand karha by separating the sub plots. Sowing was done date wise as treatment in row $45 \mathrm{~cm}$ apart using seed rate of $5 \mathrm{~kg} \mathrm{ha}^{-1}$. Later on plant spacing of $15 \mathrm{~cm}$ was maintained by thinning extra plants.

Only manual one weeding and hoeing operation were done in the experimental first weeding was done with the help of khurpi after 15-20 days of sowing and second was done after crop after first irrigation at optimum moisture, to remove the weed and to provide aeration for plant rhizosphere for proper root development of experimental crop. Extra plants were uprooted periodically right from it attains complete emergence as to maintain uniform crop geometry and represented plant population. Two irrigation was given during the crop span, first irrigation after 30-35 days of sowing and second just before the flowering stage to harvest maximum potential yield.

Plant protection measures were adopted against different insect-pests and diseases. It appeared the incidence off Alternaria blight, this disease is caused by fungus (Alternaria brassicae) affect all the aerial parts of the plant including the inflorescence and capsules. For the control of this fungal disease spray 
Mancozeb-75 WP @ 2.0kg is 1000 liters o water per hectare at 10 days interval as soon as the symptoms start appearing on the plants. In the beginning mustard saw fly larvae became active caused on the leaves, it appears in the month of October and November.

Mustard aphid is a very serious pest, both nymph and adult suck the sap of the tender leaves, twigs stem inflorescence and pods. For control of Aphids spray $0.05 \%$ malathion $50 \mathrm{EC}$ was twice during crop season.

The aphid population per $10 \mathrm{~cm}$ of terminal shoot per plant was counted in each main and sub plots at meteorological week wise. It was summed up, averaged and correlated variety wise worked out infestation of aphid.

\section{Results and Discussion}

\section{Effect of date of sowing}

The results revealed that final plant population (20.10), (Table 1) length of siliqua $(5.20 \mathrm{~cm})$ and number of seeds per siliqua (11.93) were superior with sowing date $\mathrm{D}_{1}$ being at par with sowing date $\mathrm{D}_{2}$ while Plant height at different stages, number of primary, secondary, tertiary branches / plant, dry matter production $\left(\mathrm{g} / \mathrm{m}^{2}\right)$, number of siliquae / plant at primary, secondary, tertiary branch, seed weight / plant (g), seed yield (q/ha), straw yield ( $\mathrm{q} / \mathrm{ha})$, harvest index (\%),net return, B:C ratio varied significantly among different date of sowing.

The sowing date $D_{1}$ recorded significantly higher Plant height at bolting $(13.38 \mathrm{~cm})$, branching $(33.33 \mathrm{~cm}), 50 \%$ flowering $(62.88$ $\mathrm{cm})$, silqua initial $(104.76 \mathrm{~cm})$, maturity stage $(154.66 \mathrm{~cm})$ number of primary, secondary, tertiary branches / plant $(6.57,13.58,11.27$ respectively), dry matter production $\left(\mathrm{g} / \mathrm{m}^{2}\right)$ at bolting, pod development, maturity (35.72, $67.49,75.43$ respectively), number of siliquae at primary, secondary, tertiary branch (151.30,
298.30, 74.69 respectively), Seed weight / plant (3.09 g), seed yield (16.50 q/ha), straw yield $(62.35 \mathrm{q} / \mathrm{ha})$, harvest index $(20.81 \%)$,net return (Rs 45551.0), B:C ratio(2.47). Higher values of all attributes were recorded in the result when crop was sown on November 3.

Since yield attributes of these treatments rely on the performance of vegetative growth viz. higher number of primary, secondary and tertiary branch/plant, dry matter accumulation and higher photosynthetic efficiency, which ultimately may reflect higher translocation of photosynthetic from source to sink, resulted in the terms of maximum yield. Similar results reported by Dhaliwal et al., (2005), Ray and Chakavarty (2007) Patel et al., (2010).

\section{Effect of varieties}

The observation recorded revealed that the (Table 2) mortality per cent were observed in Vaibhav followed by Varuna and lowest in Vardan whereas mustard variety $\mathrm{V}_{3}$ recorded significantly higher Plant height at bolting $(15.86 \mathrm{~cm})$, branching $(36.68 \mathrm{~cm}), \quad 50 \%$ flowering $(81.13 \mathrm{~cm})$, silqua initial $(135.15$ $\mathrm{cm})$, maturity stage $(196.48 \mathrm{~cm})$ number of primary, secondary, tertiary branches / plant (8.30, 16.55, 13.83 respectively), number of siliquae per plant at primary, secondary, tertiary branch $(202.48, \quad 345.64,93.81$ respectively), length of siliquae $(5.49 \mathrm{~cm})$,dry matter production $\left(\mathrm{g} / \mathrm{m}^{2}\right)$ at bolting, pod development, maturity (44.22), 83.29, 92.40 respectively.

Seed weight / plant (3.95 g), seed yield (20.06 q/ha), (Table 3) straw yield (71.75/ha), harvest index $(21.80 \%)$, net return (Rs 1558.88), B:C ratio(3.00). This may be attributes due to better use of photosynthetic efficiency in presence of higher foliage by the Varuna as compared to other two tested variety. The results obtained are in accordance with Saha and Khan (2008). 
Table.1 Effect of date of sowing and different varieties of mustard on growth of mustard

\begin{tabular}{|c|c|c|c|c|c|c|c|c|c|c|c|}
\hline \multirow[t]{3}{*}{ Treatment } & \multirow{2}{*}{\multicolumn{2}{|c|}{$\begin{array}{c}\text { Number of } \\
\text { plant } \\
\text { population }\left(\mathbf{m}^{2}\right)\end{array}$}} & \multirow{3}{*}{$\begin{array}{l}\text { Morta } \\
\text { lity \% }\end{array}$} & \multirow{2}{*}{\multicolumn{5}{|c|}{ Plant height }} & \multicolumn{3}{|c|}{ Number of branches / plant } \\
\hline & & & & & & & & & \multirow[t]{2}{*}{ primary } & \multirow[t]{2}{*}{ secondary } & \multirow[t]{2}{*}{ tertiary } \\
\hline & Initial & Final & & Bolting & Branching & $\begin{array}{c}50 \% \\
\text { Flowering }\end{array}$ & $\begin{array}{c}\text { Siliqua } \\
\text { initial }\end{array}$ & Maturity & & & \\
\hline \multicolumn{12}{|l|}{ Interaction } \\
\hline $\mathrm{D}_{1} \mathrm{~V}_{1}$ & 22.60 & 19.99 & 13 & 14.17 & 36.47 & 81.27 & 135.47 & 175.910 & 8.1 & 16.16 & 15.3 \\
\hline $\mathrm{D}_{1} \mathrm{~V}_{2}$ & 21.20 & 19.97 & 06 & 14.62 & 37.11 & 85.99 & 145.44 & 185.813 & 8.7 & 17.33 & 15.2 \\
\hline $\mathbf{D}_{1} \mathbf{V}_{3}$ & 22.93 & 20.35 & 13 & 17.09 & 38.51 & 92.71 & 154.95 & 221.558 & 9.2 & 19.91 & 16.4 \\
\hline $\mathbf{D}_{2} \mathbf{V}_{1}$ & 21.70 & 19.21 & 13 & 13.40 & 35.31 & 71.77 & 122.47 & 174.005 & 7.5 & 14.83 & 13.2 \\
\hline $\mathbf{D}_{2} \mathrm{~V}_{2}$ & 22.09 & 19.85 & 11 & 13.66 & 36.39 & 75.39 & 129.91 & 184.743 & 7.7 & 15.50 & 12.2 \\
\hline$D_{2} V_{3}$ & 22.70 & 19.95 & 14 & 15.61 & 38.26 & 82.88 & 134.67 & 196.040 & 8.3 & 15.58 & 13.2 \\
\hline $\mathrm{D}_{3} \mathrm{~V}_{1}$ & 21.76 & 17.98 & 21 & 12.90 & 32.51 & 57.17 & 93.56 & 143.040 & 5.2 & 13.17 & 11.2 \\
\hline $\mathrm{D}_{3} \mathrm{~V}_{2}$ & 21.96 & 18.65 & 18 & 12.36 & 33.33 & 63.69 & 104.89 & 149.083 & 7.0 & 13.41 & 10.7 \\
\hline $\mathbf{D}_{3} \mathbf{V}_{3}$ & 21.80 & 18.90 & 15 & 14.89 & 34.16 & 67.80 & 115.84 & 171.868 & 7.5 & 14.17 & 11.8 \\
\hline $\mathrm{SE} \pm(\mathrm{D} \mathrm{X} \mathrm{V})$ & 2.20 & 1.95 & - & 0.62 & 0.70 & 1.31 & 1.41 & 1.88 & 0.56 & 0.68 & 0.61 \\
\hline CD $5 \%$ & NS & NS & - & 1.29 & 1.45 & 2.72 & 2.94 & 3.91 & 1.17 & 1.42 & 1.27 \\
\hline \multicolumn{12}{|c|}{ Date of Sowing } \\
\hline 3 Nov. $\left(D_{1}\right)$ & 22.24 & 20.10 & 11 & 15.29 & 37.36 & 86.66 & 145.29 & 194.42 & 8.66 & 17.80 & 15.66 \\
\hline 10 Nov. $\left(D_{2}\right)$ & 20.83 & 19.67 & 06 & 14.22 & 36.65 & 76.68 & 129.01 & 184.92 & 7.83 & 15.30 & 12.85 \\
\hline 17 Nov. $\left(D_{3}\right)$ & 21.85 & 18.35 & 19 & 13.38 & 33.33 & 62.88 & 104.76 & 154.66 & 6.57 & 13.58 & 11.27 \\
\hline $\mathrm{SE} \pm(\mathrm{D})$ & 0.51 & 0.33 & - & 0.34 & 0.26 & 0.71 & 0.66 & 1.40 & 0.35 & 0.24 & 0.46 \\
\hline CD 5\% & NS & 0.83 & - & 0.84 & 0.66 & 1.78 & 1.65 & 3.50 & 0.89 & 0.62 & 1.15 \\
\hline \multicolumn{12}{|l|}{ Variety } \\
\hline Vaibhav $\left(V_{1}\right)$ & 21.69 & 19.06 & 14 & 13.49 & 34.76 & 70.07 & 117.17 & 164.31 & 6.93 & 13.16 & 13.24 \\
\hline Vardan $\left(\mathbf{V}_{2}\right)$ & 21.09 & 19.49 & 08 & 13.55 & 35.61 & 75.02 & 126.74 & 173.21 & 7.73 & 15.41 & 12.71 \\
\hline Varuna $\left(V_{3}\right)$ & 22.15 & 19.58 & 13 & 15.86 & 36.68 & 81.13 & 135.15 & 196.48 & 8.30 & 16.55 & 13.83 \\
\hline $\mathrm{SE}+(\mathrm{V})$ & 0.52 & 0.21 & - & 0.36 & 0.44 & 0.77 & 0.86 & 0.95 & 0.31 & 0.43 & 0.30 \\
\hline CD 5\% & NS & NS & - & 0.77 & 0.93 & 1.63 & 1.82 & 2.03 & 0.66 & 0.91 & 0.65 \\
\hline
\end{tabular}


Table.2 Effect of date of sowing and different varieties of mustard on growth and yield attributes of mustard

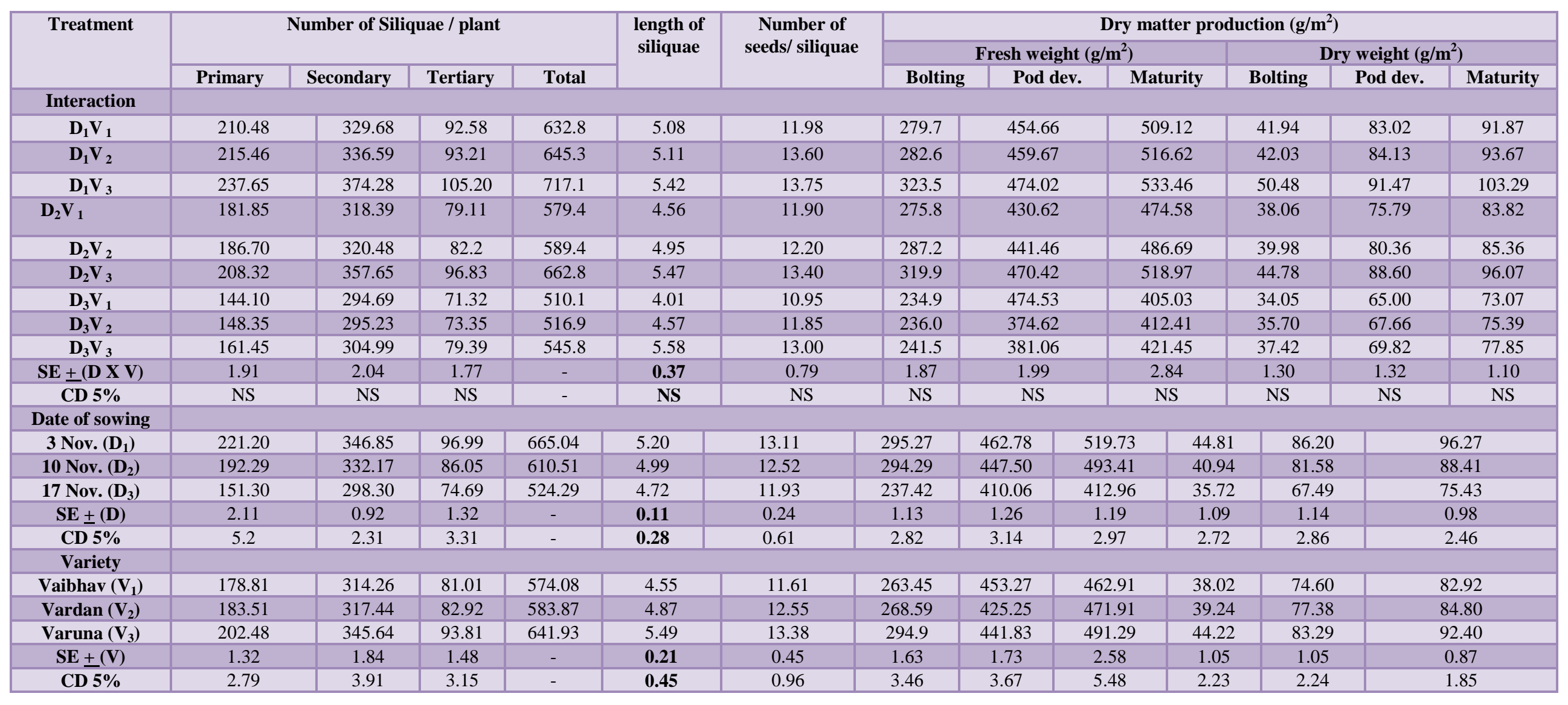


Table.3 Yield and economics of production of mustard as influenced by different treatments

\begin{tabular}{|c|c|c|c|c|c|c|}
\hline Treatment & $\begin{array}{c}\text { Seed } \\
\text { weight / } \\
\text { plant (g) }\end{array}$ & $\begin{array}{l}\text { Seed yield } \\
\text { (q/ha) }\end{array}$ & $\begin{array}{c}\text { Straw yield } \\
\text { (q/ha) }\end{array}$ & $\begin{array}{c}\text { Harvest } \\
\text { index }(\%)\end{array}$ & Net return & $\mathrm{B}: \mathrm{C}$ ratio \\
\hline \multicolumn{7}{|l|}{ Interaction } \\
\hline $\mathbf{D}_{1} \mathbf{V}_{1}$ & 4.35 & 20.02 & 73.80 & 21.33 & 61689.5 & 3.00 \\
\hline $\mathbf{D}_{1} \mathbf{V}_{2}$ & 4.50 & 20.97 & 77.25 & 21.43 & 66086.00 & 3.14 \\
\hline $\mathbf{D}_{1} \mathbf{V}_{3}$ & 4.67 & 22.17 & 77.30 & 22.25 & 71186.00 & 3.31 \\
\hline $\mathbf{D}_{2} \mathrm{~V}_{1}$ & 3.42 & 17.60 & 65.67 & 21.39 & 50561.00 & 2.64 \\
\hline $\mathrm{D}_{2} \mathrm{~V}_{2}$ & 3.52 & 18.00 & 67.00 & 21.25 & 52391.00 & 2.70 \\
\hline $\mathbf{D}_{2} \mathrm{~V}_{3}$ & 3.85 & 19.97 & 71.60 & 22.01 & 61266.00 & 2.98 \\
\hline $\mathbf{D}_{3} \mathrm{~V}_{\mathbf{1}}$ & 2.90 & 15.20 & 58.7 & 20.48 & 39661.00 & 2.28 \\
\hline $\mathbf{D}_{3} \mathbf{V}_{2}$ & 3.05 & 16.25 & 62.02 & 20.82 & 44453.50 & 2.44 \\
\hline $\mathbf{D}_{3} V_{3}$ & 3.32 & 18.05 & 66.35 & 21.13 & 52543.00 & 2.70 \\
\hline $\mathrm{SE}+(\mathrm{D} X \mathrm{~V})$ & 0.18 & 0.79 & 1.75 & 0.34 & 1342.18 & 0.19 \\
\hline$\overline{C D} 5 \%$ & N.S. & NS & NS & N.S. & 2786.62 & 2.69 \\
\hline \multicolumn{7}{|l|}{ Date of sowing } \\
\hline 3 Nov. $\left(D_{1}\right)$ & 4.50 & 21.05 & 76.11 & 21.67 & 66264.00 & 3.15 \\
\hline 10 Nov. $\left(\mathrm{D}_{2}\right)$ & 3.60 & 18.52 & 68.09 & 21.55 & 54710.00 & 2.77 \\
\hline 17 Nov. $\left(\mathbf{D}_{3}\right)$ & 3.09 & 16.50 & 62.35 & 20.81 & 45551.00 & 2.47 \\
\hline $\mathrm{SE} \pm(\mathrm{D})$ & 0.10 & 0.22 & 1.79 & 0.22 & 880.64 & 0.12 \\
\hline CD $5 \%$ & 0.27 & 0.55 & 4.46 & 0.56 & 2196.75 & 0.30 \\
\hline \multicolumn{7}{|l|}{ Variety } \\
\hline Vaibhav $\left(V_{1}\right)$ & 3.55 & 17.60 & 66.05 & 21.07 & 50596.00 & 2.64 \\
\hline Vardan $\left(V_{2}\right)$ & 3.69 & 18.40 & 68.75 & 21.16 & 54266.00 & 2.76 \\
\hline Varuna $\left(V_{3}\right)$ & 3.95 & 20.06 & 71.75 & 21.8 & 61621.00 & 3.00 \\
\hline $\mathrm{SE}+(\mathrm{V})$ & 0.10 & 0.46 & 1.01 & 0.19 & 736.29 & 0.10 \\
\hline CD $5 \%$ & 0.22 & 0.97 & 2.14 & 0.41 & 1558.88 & 0.22 \\
\hline
\end{tabular}




\section{Interaction effect}

The interaction of date of sowing and varieties were significant with respect to plant height at bolting, 50\% flowering, siliqua initial, maturity stage, No. of secondary branch per plant, net return, $\mathrm{B}: \mathrm{C}$ ratio. The combination of $\mathrm{D}_{1} \mathrm{~V}_{3}$ i.e., mustard variety vaibhav sown on date 3 Nov. recorded significantly higher plant height at bolting, 50\% flowering, siliqua initial, maturity stage $(17.09,92.71,154.95$, 221.558 respectively), No. of secondary branch per plant (19.91), net return (Rs 71186.0), B:C ratio (3.31). Similar findings were reported by Mall et al., (2004) and Mandal and Sinha (2002).

Based on the study it is calculated that $3^{\text {rd }}$ Nov. sowing date and variety Varuna proved beneficial for farmers and better option for realizing higher productivity of mustard in irrigated condition under Central Plain Zone of U.P.

\section{References}

Anonymous, 2007.Statistical analysis of Himachal Pradesh. Department of Economics and Statistics, Himachal Pradesh, pp. 69-71.

Dhaliwal, L.K. 2002. Crop weather aphid interaction in Raya (Brassica juncea L.) Under different hydrothermal environment. Ph.D. Dissertation, Punjab Agricultural University, Ludhiana.

Dhaliwal, L.K., Hundal, S.S. and Chahal, S.K. 2007.Agroclimatic indices of Indian mustard (Brasica juncia) under Punjab conditions. Indian Journal of Agricultural Sciences. 77 (2): 88-91.

Hundal, S.S., Kaur, $\mathrm{P}$ and Malikpuri.S.D.S. 2004. Radiation use efficiency of mustard cultivars under different sowing dates. J. Agromet., 6(1): 70-75.

Kar, G. and Chakravarty, N.V.K.
2000.Predicting crop growth and aphid incidence in Burasica under semi arid environmental. Indian J. Agric. CSU.70: 3-7.

Krishna Murthy and Bhatnagar 1989. Reported that the time of sowing plays a key role in modifying the length of vegetative and reproductive phase in this crop and mitigates the effects of weather variability, modification in sowing dates could be one option for optimizing the growth and seed yield.

Kumar, A., Singh, D.P, Yadev, Y.P and Singh, B. 1998. Association between morphophysiological parameters and seed yield in Brassica genotypes. Cruciferae-Newsletter., No. 20, 69-70.

Lallu, Baghel, R.S., Srivastava, S.B.L., 2010. Assessment of mustard genotypes thermo-tolerance at seed development stage, Indian J. Plant Physiology, 15 (1): 36-43.

Mall, R.K., Lal, M., Bhatia, V.S., Rathore, L.S., Singh, R. 2004. Mitigating climate change impact on soyabean productivity in India: a simulation study. Agric. Forest Meteorol. 121: 113-125.

Mandal, K.G. and Sinha, A.C. 2002. Effect of integrated nutrient management on growth, yield, oil content and nutrient uptake of Indian mustard (Brassica Juncea) in foot hills soils of eastern India. Indian Journal of Agronomy, 47 (1): 109-113 (March 2002).

Patel, G.G., Patel, H.R., Shekh, A.M., Ujinwall, M.K., Patel, J.S., Pandey, V., Vadodaria, R.P and Bhatt, B.K. 2010. Role of weather parameters on seed yield of mustard in middle Gujarat Agro-climatic region. Agrometeorological services for farmers. Ed. Vyaspandey, P.P.79.

Roy, Sumana and Chakravarty, N.V.K. 2007. Phenological development and biomass partitioning in Brassica as 
influenced by weather conditions. Yadav, P.N., Uttam, S.K., Singh, R.P. and Journal of Agrometeorology, 9 (2): Kaushal Kumar 1996.Effect of 216 - 222 (Dec. 2007).

Saha, G. and Khan, S.A. 2008. Predicting yield and yield attributes of yellow sarson with agrometeorological parameters. Journal of Agrometeorology, (Special issue - part fertilizer and moisture conservation on productivity, economics and water use efficiency (Brassica juncea L.). Current Advances in Agricultural Sciences, 3(2), 108-111. 8 ref I): $115-119$.

\section{How to cite this article:}

Naresh Chand, A. P. Dubey, Thaneshwar, Jai Prakash and Vipin Kumar Sagar. 2019. Productivity and Economics under Varying Sowing Time of Mustard (Brassica juncea L.) Varieties in Central Uttar Pradesh. Int.J.Curr.Microbiol.App.Sci. 8(10): 1355-1363. doi: https://doi.org/10.20546/ijcmas.2019.810.158 